Abstract

\title{
Link between Land Use and Flood Risk Assessment in Urban Areas ${ }^{\dagger}$
}

\author{
Zahra Kalantari ${ }^{1, *}$ and Johanna Sörensen ${ }^{2}$ \\ 1 Department of Physical Geography and Bolin Centre for Climate Research, Stockholm University, \\ SE-106 91 Stockholm, Sweden \\ 2 Water Resources Engineering, Lund University, 22100 Lund, Sweden; johanna.sorensen@tvrl.lth.se \\ * Correspondence: zahra.kalantari@natgeo.su.se \\ + Presented at TERRAenVISION 2019, Barcelona, Spain, 2-7 September 2019.
}

Published: 19 May 2020

\begin{abstract}
The densification of urban areas has raised concerns over increased pluvial flooding. Flood risk in urban areas might increase under the impact of land use changes. Urbanisation involves the conversion of natural areas to impermeable areas, causing lower infiltration rates and increased runoff. When high-intensity rainfall exceeds the capacity of an urban drainage system, the runoff causes pluvial flooding in low-laying areas. In the present study, a long time series (i.e., 20 years) of geo-referenced flood claims from property owners has been collected and analysed in detail to assess flood risk as it relates to land use changes in urban areas. The flood claim data come from property owners with flood insurance that covers property loss from overland flooding, groundwater intrusion through basement walls, as well as flooding from drainage systems; these data serve as a proxy of flood severity. The spatial relationships between land use change and flood occurrences in different urban areas were analysed. Special emphasis was placed on examining how nature-based solutions and blue-green infrastructure relate to flood risk. The relationships are defined by a statistical method explaining the tendencies whereby land use change affects flood risk.
\end{abstract}

Keywords: flood risk; flood severity; flood insurance; urbanisation; land use

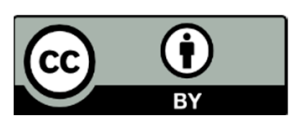

(C) 2020 by the authors. Licensee MDPI, Basel, Switzerland. This article is an open access article distributed under the terms and conditions of the Creative Commons Attribution (CC BY) license (http://creativecommons.org/licenses/by/4.0/). 